\title{
CONCENTRATION DISTRIBUTION OF HEAVY METALS IN MANILA CLAM (RUDITAPES PHILIPPINARUM) AND POTENTIAL HEALTH RISK IN THE COASTAL AREAS OF LIAODONG BAY, CHINA
}

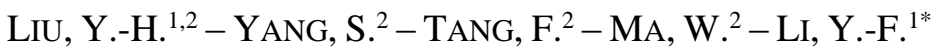 \\ ${ }^{1}$ College of Veterinary, Northeast Agricultural University \\ HarBin 150030, Hei Longjiang Province, China \\ ${ }^{2}$ College of Animal Husbandry and Veterinary, Jinzhou Medical University \\ Jinzhou 121000, Liaoning Province, China \\ *Corresponding author \\ e-mail:bdlyh@163.com \\ (Received 24 $4^{\text {th }}$ May 2019; accepted $10^{\text {th }}$ Oct 2019)
}

\begin{abstract}
Arsenic (As), Cadmium (Cd), Chromium (Cr), Copper (Cu), Lead (Pb), and Zinc ( $\mathrm{Zn})$ concentrations in Manila clam from Liaodong Bay (China) were determined by inductively coupled plasma mass spectrometry. Tissue-specific bioaccumulation, geographical variability (using metal pollution indices) and health risks (using target hazard quotients and maximum daily consumption values) were assessed. Cd concentrations were high at all sampling sites, particularly S6 and S7, where it reached Category III. Other metal concentrations were high at S7 (As), S1 (Cr), S5 (Pb), and S5 and S7 (Zn). As, $\mathrm{Cr}$ and $\mathrm{Cu}$ accumulated to a higher degree in the viscera than muscles, but $\mathrm{Cd}$ accumulated more in muscles than viscera. Heavy metal (HM) contamination was worse in the west than that in the east. The $\mathrm{Cd}$ target hazard quotients were greater than 1, but the other HM target hazard quotients were less than 1 at all sites, indicating $\mathrm{Cd}$ posed the greatest health risks to humans. The maximum daily consumption values also indicated $\mathrm{Cd}$ poses health risks.
\end{abstract}

Keywords: heavy metals, clam, bioaccumulation, geographical variability, health risk estimate, Liaodong Bay

\section{Introduction}

Liaodong Bay is one of the three main bays in the Bohai Sea. Water exchange between Liaodong Bay and the open sea is slow, so pollutants are not readily transported out of Liaodong Bay. Many rivers (e.g., the Dalinghe River, Liaohe River, and Xiaolinghe River) flow into the bay area. There are cities of different sizes around Liaodong Bay, and large parts of the coast are occupied by harbors, industrial areas and aquaculture facilities. Large amounts of domestic sewage and industrial effluent containing various pollutants are discharged into Liaodong Bay (Zhang et al., 2016; Naser, 2013; Gargouri et al., 2011; Wan et al., 2008a). These wastewaters also contain large amount of heavy metals (HMs). HM contamination is a serious issue around the world (Zhang et al., 2016; Gao and Chen, 2012; Hu et al., 2013).

HMs are persistent, stable, toxic, non-biodegradable, and bioaccumulative. HMs can accumulate in organisms and can cause many diseases ( $\mathrm{Li}$ et al., 2015). HMs in the marine environment therefore pose health risks to aquatic organisms and humans consuming aquatic organisms. It is necessary to determine HM concentrations in aquatic media and organisms to gain an understanding of the health risks posed by contaminated seafood to humans consuming (Wei et al., 2014; Li et al., 2015). 
Bivalves as benthic species can accumulate many pollutants, including HMs, to which they are very tolerant. Bivalves are therefore used as bioindicators of HM contamination in aquatic systems (Li and Gao, 2014; Won et al., 2016; ShoultsWlison et al., 2015). The bivalve Manila clam (Ruditapes philippinarum, Rud) is generally found in sediment and tends to accumulate HMs present in the sediment (Zhao et al., 2012). Rud is easily collected in Liaodong Bay. Rud is considered to be delicious, and is consumed in large quantities. Determining the concentrations of HMs in Rud in Liaodong Bay will allow HM pollution of the aquatic environment and health risks posed to humans consuming contaminated seafood to be assessed (Liang et al., 2004).

In previous studies of $\mathrm{HM}$ in the Bohai Sea, most sampling sites were located along the Bohai Bay coast (Li et al., 2015; Zhang et al., 2016; Wang et al., 2005) and in Laizhou Bay (Liu et al., 2017). Few sampling sites in Liaodong Bay were used. In this study, we determined the concentrations of Arsenic (As), Cadmium (Cd), Chromium $(\mathrm{Cr})$, Copper $(\mathrm{Cu})$, Lead $(\mathrm{Pb})$, and Zinc $(\mathrm{Zn})$ in muscles and viscera from Rud collected from seven sites along the Liaodong Bay coast. The main objectives were 1) to determine HM concentrations in Rud from the different sampling sites, 2) to assess tissue-specific HM bioaccumulation by Rud 3) to assess geographical variability in HM concentrations in Rud using metal pollution indices (MPIs), and 4) to assess the risks posed by HMs in Rud to human health using national and international guidelines, target hazard quotients (THQs), and maximum daily consumption rates $\left(\mathrm{CR}_{\max } \mathrm{S}\right)$.

\section{Materials and methods}

Samples were collected from seven sites along the coastal area of Liaodong Bay (China) in July and August 2017, which is the main fishing season (Fig. 1). Attached mud and debris was removed from the surface of each shell. The Rud weights and shell lengths were measured. Muscle and viscera tissue samples were collected. Muscle tissue from three individuals were combined and homogenized to form a single sample. Viscera from 15 individuals were combined and homogenized to form a single sample to provide sufficient analytes for analysis (Liu et al., 2017). Six mixed muscle samples and six viscera samples from each sampling site were analyzed. The samples were lyophilized and ground into powder. The samples were analyzed using a previously described method ( $\mathrm{Li}$ et al., 2015). Briefly, $0.2 \mathrm{~g}$ of a dry sample was placed in a polytetrafluoroethylene tube containing $3 \mathrm{~mL} \mathrm{HNO}_{3}$ (65\%) (Suprapur; Merck, Damstadt, Germany) and $1 \mathrm{~mL} \mathrm{H}_{2} \mathrm{O}_{2}$ (35\%) (Suprapur; Merck). The tube was then placed in a Mars-5 microwave digestion instrument (CEM, Buckingham, UK) to digest the mixture. The digest was then diluted to $50 \mathrm{~mL}$ with ultrapure water and passed through a $0.45 \mu \mathrm{m}$ membrane filter. The HM concentrations in the digest were determined using an Agilent 7500i inductively coupled plasma mass spectrometer (Agilent Technologies, Santa Clara, CA, USA). A standard reference material (GBW08571, mussel tissue) was analyzed to ensure the HM analysis method gave acceptable results. The mean recovery rates of the metals that were analyzed in the reference material samples were $82-112 \%$.

The MPI was calculated for each sampling site to allow geographical variability in the HM concentrations in the Rud tissues to be assessed (Liu et al., 2017). The MPI was calculated using Equation 1: 


$$
M P I=\left(C f_{1} \times C f_{2} \times \cdots \times C f_{n}\right)^{\frac{1}{n}}
$$

where Cf1 is the concentration of the first HM in muscle tissue (in this study) from the sampling site of interest, Cf2 is the concentration of the second HM, Cfn is the concentration of the nth HM, and $\mathrm{n}$ is the total number of HMs analyzed.

The risks posed by HMs in Rud to human health were assessed using THQs and $\mathrm{CR}_{\max }$ (US EPA, 2000; $\mathrm{Li}$ et al., 2015). The THQs and $\mathrm{CR}_{\max }$ sere calculated from the HM concentrations in the muscle samples using Equations 2 and 3:

$$
T H Q=\frac{C \times W_{\text {clam }} \times E D \times E F}{B W \times \operatorname{RfD} \times A t n} \times 10^{-3}
$$

and

$$
C R_{\max }=\frac{R f D \times B W}{C}
$$

where $\mathrm{C}$ is the mean concentration of a HM in Rud muscle (in $\mathrm{mg} / \mathrm{kg}$ wet weight (ww)), $\mathrm{W}_{\text {clam }}$ is the daily Rud ingestion rate for an adult $(38.9 \mathrm{~g} / \mathrm{d})$ (National Bureau of Statistics of China, 2009), ED is the exposure duration (74.8 y, the expected average lifetime) (MEP, 2013), EF is the exposure frequency ( $365 \mathrm{~d} / \mathrm{y}), \mathrm{BW}$ is the average body weight (63 kg for an adult) (National Physique Monitoring Center of China, 2012), RfD is the average oral reference dose for the HM of interest (US EPA, 2014), Atn is the average exposure time for a non-carcinogen $(E D \times 365 \mathrm{~d} / \mathrm{y})$, and $10^{-3}$ is the unit conversion factor.

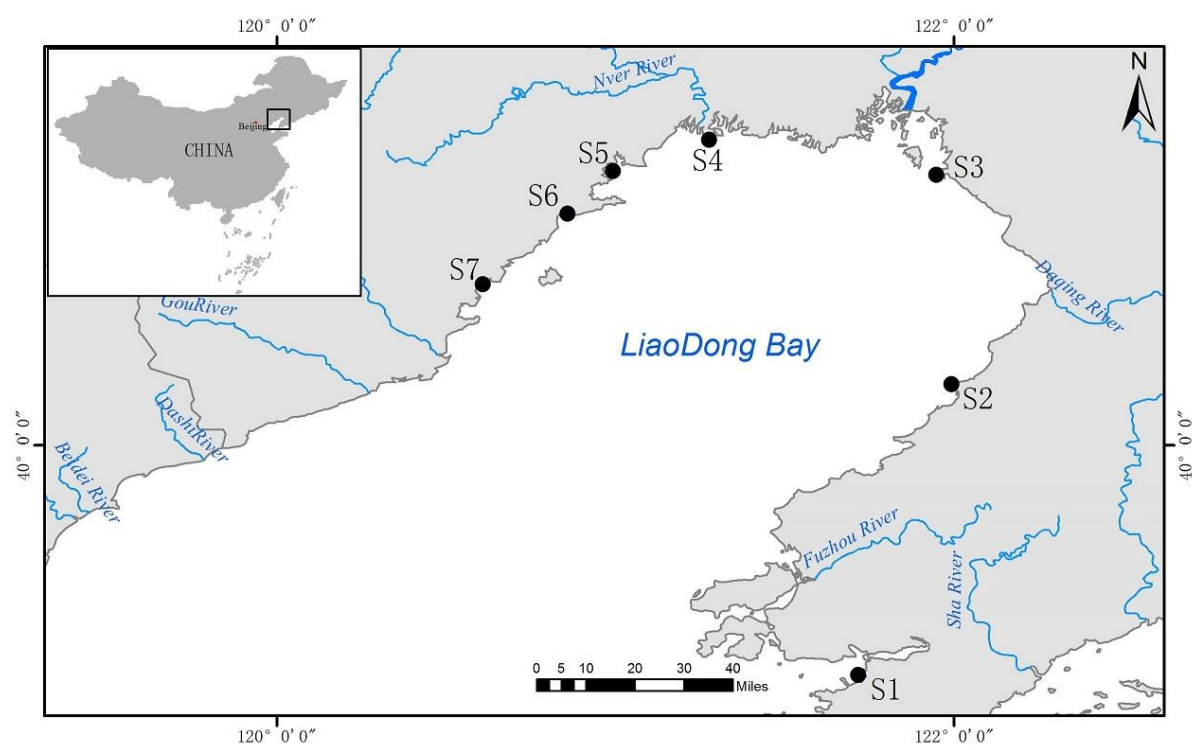

Figure 1. Map of sampling sites at the Liaodong Bay, China. S1, Puwan $\left(39^{\circ} 19^{\prime} 16.15785^{\prime \prime} \mathrm{N}\right.$,

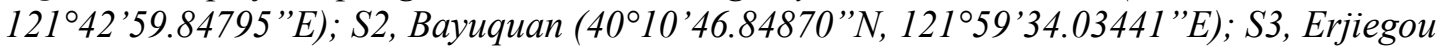

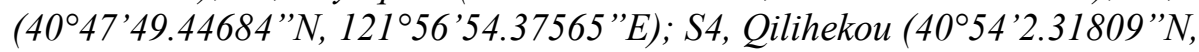

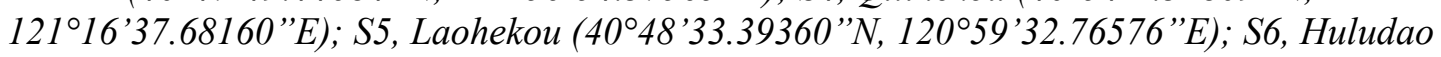
$\left(40^{\circ} 41^{\prime} 0.69727^{\prime \prime} N, 120^{\circ} 51\right.$ '31.40488”'E); S7, Shahousuo $\left(40^{\circ} 28^{\prime} 27.18772 ” N\right.$, 
Data analyses were performed using SPSS 18.0 software (IBM, Armonk, NY, USA). Each result is expressed as the mean \pm standard deviation. ANOVA, SNK, and post hoc multiple comparisons, etc. were used to detect differences between groups. Differences between results for groups of samples were considered to be statistically significant at $\mathrm{P}<0.05$.

\section{Results}

\section{Heavy metal concentrations in Rud}

The HM concentrations found in the Rud muscle and viscera samples from each sampling site are shown in Figure 2. The $\mathrm{Cd}$ concentrations were quite high in the samples from all of the sites, particularly S6 and S7, the samples from which had Cd concentrations much higher than the Category III standard for $\mathrm{Cd}$. The $\mathrm{Cd}$ concentrations in the samples from sites S1, S3, and S4 exceeded the Category II standard. The maximum permissible level for $\mathrm{Cd}$, set by the World Health Organization in 1982 , is $2 \mathrm{mg} / \mathrm{kg} \mathrm{ww}$, which is equivalent to the Category II standard. This indicated that attention needs to be paid to Cd pollution in Liaodong Bay. The As concentrations were higher in the samples from site S7 than in the samples from the other sites. The As concentration in the viscera samples from site S7 exceeded the Category II standard for As. The Cr concentrations were higher in the samples from site S1 than in the samples from the other sites but lower than the Category II standard for $\mathrm{Cr}$. The $\mathrm{Cu}$ concentrations in all of the samples were low and were lower than the Category I standard for $\mathrm{Cu}$. The $\mathrm{Pb}$ concentrations were higher in the samples from site $\mathrm{S} 5$ than in the samples from the other sites but were lower than the Category II standard for $\mathrm{Pb}$. The $\mathrm{Pb}$ concentrations in the samples from the other sites were lower. The $\mathrm{Zn}$ concentrations in the samples from sites S5 and S7 exceeded the Category II standard.
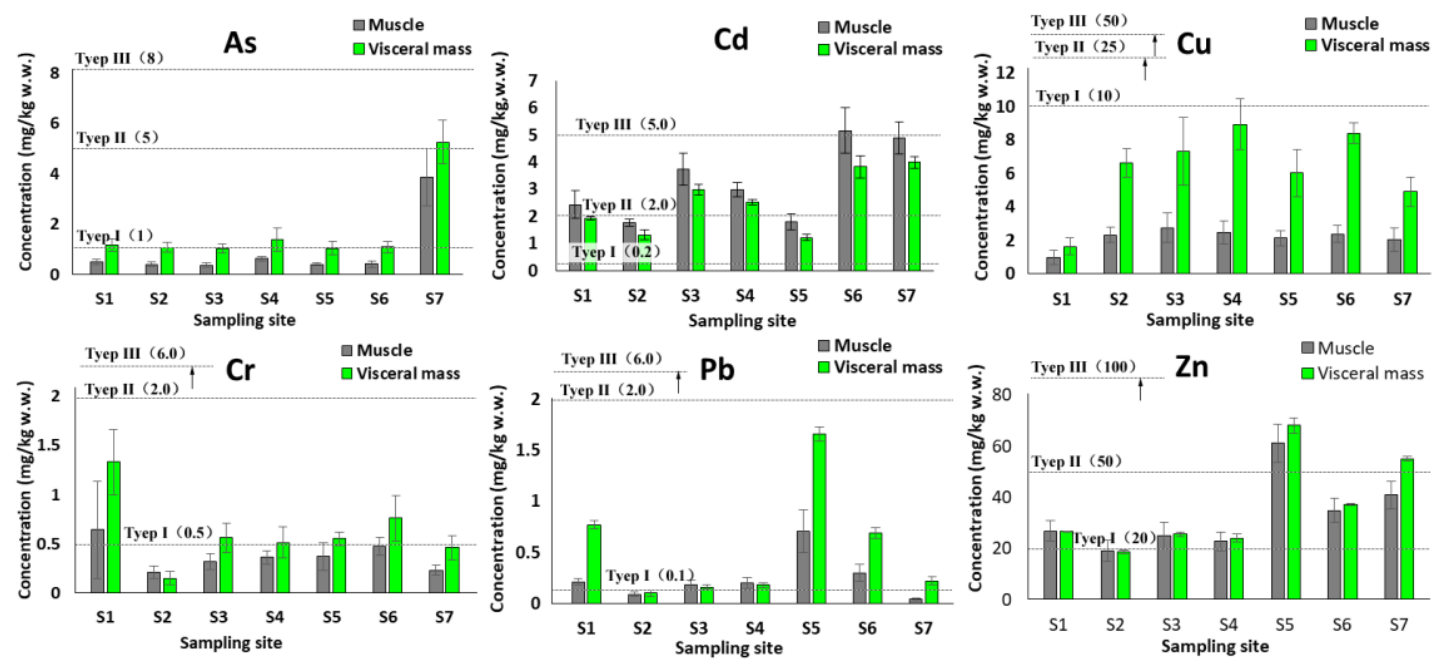

Figure 2. Concentration ranges of heavy metals in different tissues at different sampling sites

According to the standard (Table 1; Fig. 2), the concentrations of $\mathrm{Cd}, \mathrm{Pb}$ and $\mathrm{Zn}$ in Rud have exceeded the allowable limits. Moreover, compared with previous studies (Table 1), the concentration of $\mathrm{Cd}$ was the highest and the others were present at a moderate level in the Liaodong Bay. 
Table 1. Comparison of heavy metal concentrations in the soft tissues of shellfish from the Liaodong Bay, other areas in China, and world marine waters

\begin{tabular}{|c|c|c|c|c|c|c|c|c|c|c|}
\hline Site & Species & & Year & As & Cd & $\mathrm{Cr}$ & $\mathrm{Cu}$ & $\mathbf{P b}$ & Zn & Reference \\
\hline Liaodong Bay & Ruditapes philippinarum & w. w. & 2017 & 0.92 & 3.27 & 0.37 & 2.15 & 0.25 & 32.82 & This study \\
\hline Shanghai & Mactra chinensis & d. w. & $\begin{array}{l}2008 \\
2009\end{array}$ & 0.2 & 0.03 & 0.1 & & 0.13 & 14.8 & Lei et al., 2013 \\
\hline A site of Bohai Bay & \multirow{3}{*}{ Mactra veneriformis } & w.w. & 2008 & 1.44 & 0.27 & 1.37 & 2.34 & 0.37 & 11.57 & \multirow{3}{*}{ Li et al., 2015} \\
\hline B site of Bohai Bay & & & & 1.51 & 0.45 & 1.95 & 1.98 & 0.56 & 14.56 & \\
\hline C site of Bohai Bay & & & & 2.51 & 0.47 & 0.49 & 1.05 & 0.17 & 20.65 & \\
\hline \multirow{3}{*}{ Laizhou Bay } & Ark shell & w.w. & 2011 & 30.4 & 1.3 & 0.25 & 1.17 & 0.1 & 17.53 & \multirow{3}{*}{ Liu et al., 2017} \\
\hline & Surf clam & & & 1.16 & 0.22 & 0.48 & 1.11 & 0.21 & 9.89 & \\
\hline & Manila clam & & & 3.08 & 0.26 & 0.38 & 1.78 & 0.22 & 21.35 & \\
\hline Daya Bay & Perna viridis & w.w. & 2015 & 0.54 & 0.006 & 1.07 & 0.69 & 0.07 & 10.76 & Gu et al., 2016 \\
\hline Catania Gulf & D. trunculus & w.w. & 2012 & 1.53 & 0.01 & 0.25 & & 0.07 & 7.63 & Copat et al., 2013 \\
\hline Adriatic coastal area & Mytilus galloprovincialis & d.w. & 2009 & & 1.72 & & 5.31 & 3.79 & 111.2 & Jovic and Stankovic, 2014 \\
\hline Venezuelan coast & Crassostrea rhizophorae & d.w. & $\begin{array}{l}2008 \\
2009\end{array}$ & & 2.5 & 1.2 & 50.4 & 2.6 & 563.3 & Alfonso et al., 2013 \\
\hline Grade I. & Shellfish & w.w & & 1.0 & 0.2 & 0.5 & 10 & 0.1 & 20 & SEPA, 2001 \\
\hline Grade II. & Shellfish & w.w & & 5.0 & 2.0 & 2.0 & 25 & 2.0 & 50 & SEPA, 2001 \\
\hline Grade III. & Shellfish & w.w & & 8.0 & 5.0 & 6.0 & 50 & 6.0 & 100 & SEPA, 2001 \\
\hline
\end{tabular}

w.w.: wet weight, d.w.: dry weight

\section{Tissue-specific bioaccumulation of HMs in Rud}

The results of one-way analyses of variance in the HM concentrations in the muscle and viscera samples are summarized in Table 2. The concentrations in the muscle and viscera samples were significantly different for $\mathrm{As}, \mathrm{Cd}, \mathrm{Cr}$, and $\mathrm{Cu}(\mathrm{p}<0.05)$ but not for $\mathrm{Zn}$ and $\mathrm{Pb}(\mathrm{p}>0.05)$. Different tissue-specific bioaccumulation patterns were found for different metals (Fig. 3). The Cd concentrations were significantly higher in the muscle samples than the viscera samples ( $\mathrm{p}<0.05)$. The $\mathrm{As}, \mathrm{Cr}$, and $\mathrm{Cu}$ concentrations were significantly higher in the viscera samples than the muscle samples $(p<0.05)$.

Table 2. One-way ANOVA results running on the heavy metal concentrations ( $\mathrm{mg} / \mathrm{kg}$ wet wt) in the muscles and visceral masses of Rud from Liaodong Bay

\begin{tabular}{c|c|c|c|c|c|c}
\hline $\mathbf{H M}$ & $\mathbf{C d}$ & $\mathbf{C r}$ & $\mathbf{A s}$ & $\mathbf{C u}$ & $\mathbf{Z n}$ & $\mathbf{P b}$ \\
\hline $\mathrm{F}$ & 4.29 & 10.93 & 4.59 & 65.76 & 0.73 & 9.40 \\
$\mathrm{p}$ & 0.043 & 0.002 & 0.036 & 0.002 & n.s. & n.s. \\
\hline
\end{tabular}

n.s.: no statistical difference

\section{Geographical variability in the HM concentrations in Rud}

\section{HM concentrations in samples from different areas}

Comparison of the HM concentrations ( $\mathrm{mg} / \mathrm{kg}$ dry wt) in the muscles of Rud in different sampling regions of Liaodong Bay are summarized in Figure 4. The west coast is $\mathrm{S} 4-\mathrm{S} 7$, and the east coast is $\mathrm{S} 1-\mathrm{S} 3$. The As, $\mathrm{Cd}$, and $\mathrm{Pb}$ concentrations were significantly higher along the west coast than along the east coast $(\mathrm{p}<0.05)$. The $\mathrm{Cr}$, $\mathrm{Cu}$, and $\mathrm{Zn}$ concentrations along the east and west coasts were not significantly different $(\mathrm{p}>0.05)$. 


\section{Rud MPIs in different areas}

MIPs were calculated according to Equation 1. The MPIs for the different sampling sites are summarized in Table 3. The MPIs for the sampling sites decreased in the order $\mathrm{S} 4>\mathrm{S} 5>\mathrm{S} 6>\mathrm{S} 7>\mathrm{S} 3>\mathrm{S} 1>\mathrm{S} 2$. The MPIs were higher for the west coast (sites S4S7) than the east coast (sites S1-S3). These results indicated that HM contamination is more serious along the west coast than the east coast.

Table 3. MPI values of Rud in different sampling sites of Liaodong Bay

\begin{tabular}{c|c|c|c}
\hline Eastern site & MPI & Western site & MPI \\
\hline S1 & 3.36 & S4 & 4.61 \\
S2 & 2.70 & S5 & 4.50 \\
S3 & 3.71 & S6 & 4.45 \\
& & S7 & 3.93 \\
\hline Mean value & 3.26 & Mean value & 4.37 \\
\hline
\end{tabular}

As

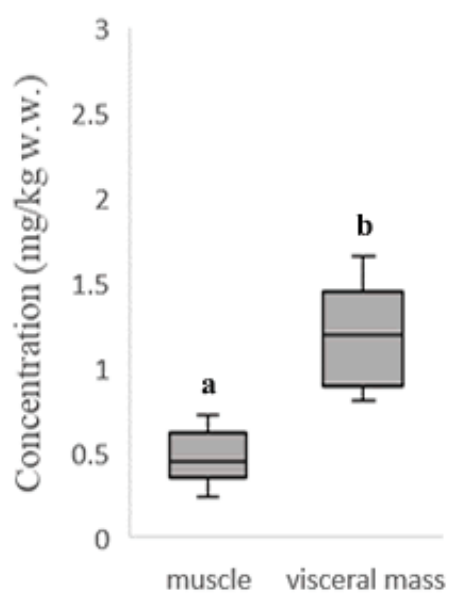

$\mathrm{Cu}$

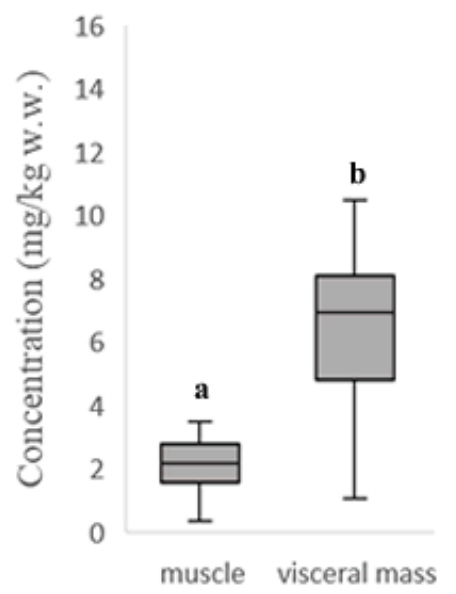

$\mathrm{Cd}$

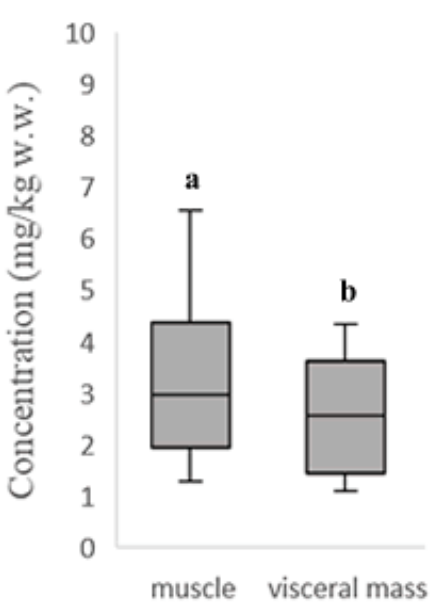

$\mathrm{Pb}$

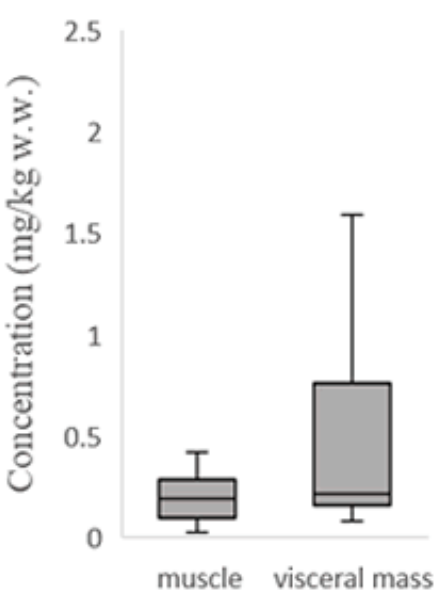

$\mathrm{Cr}$

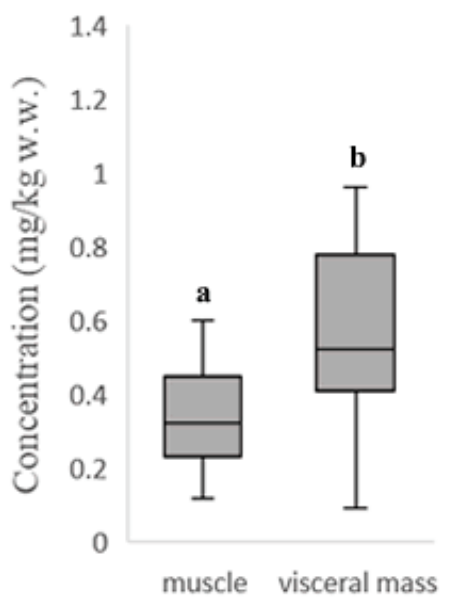

$\mathrm{Zn}$

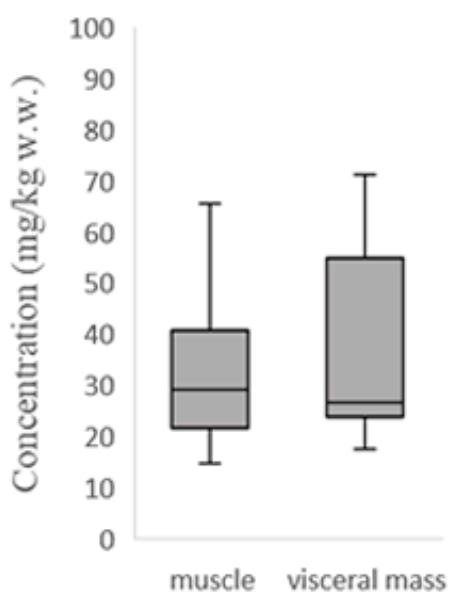

Figure 3. Boxing plotting of the heavy metal concentrations ( $\mathrm{mg} / \mathrm{kg}$ dry wt) in the tissues of Rud from Liaodong Bay. Different superscript letters indicate significant differences at $p<0.05$

$$
(n=6)
$$


As
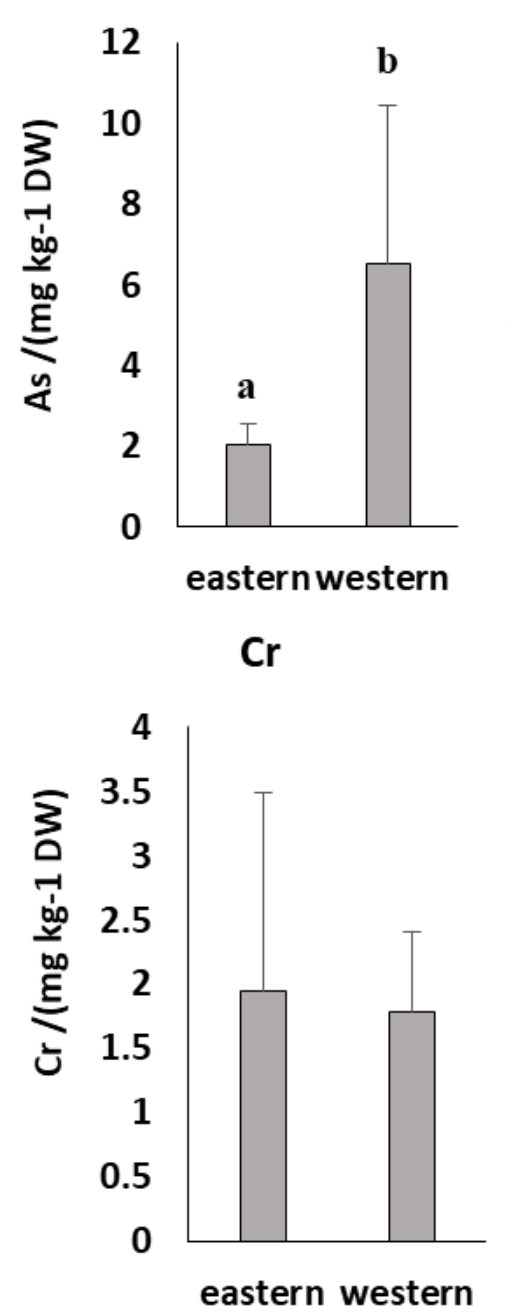

Cd

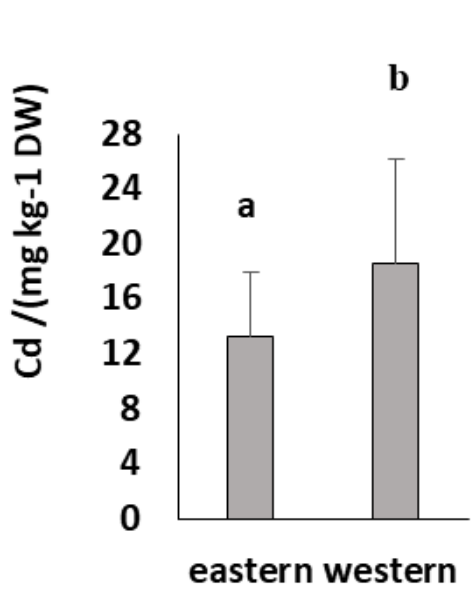

$\mathrm{Pb}$

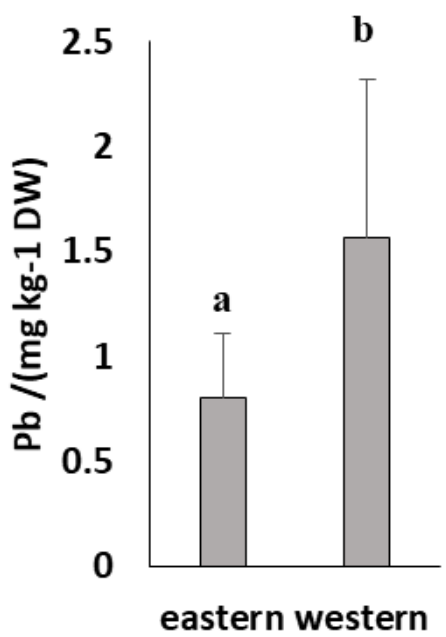

$\mathrm{Cu}$

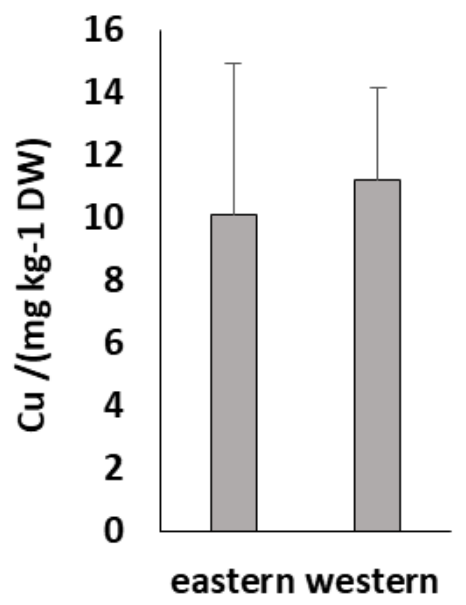

$\mathrm{Zn}$

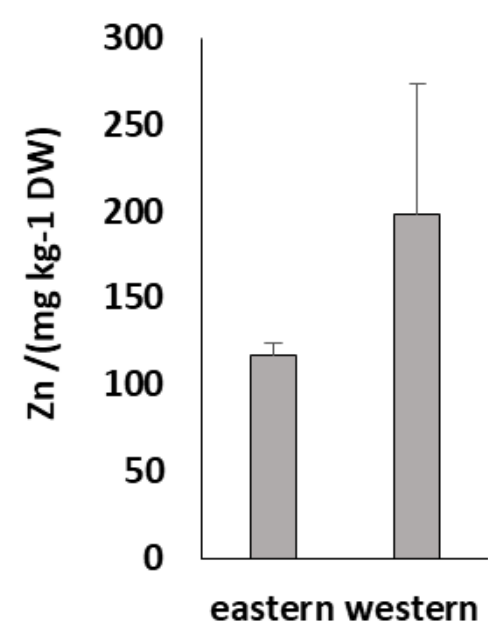

Figure 4. Comparison of the heavy metal concentrations ( $\mathrm{mg} / \mathrm{kg}$ dry $w \mathrm{t}$ ) in the muscles of Rud in different sampling regions of Liaodong Bay. Different superscript letters indicate significant differences at $p<0.05(n=6)$

\section{Health risks posed to humans by HMs in Rud}

The HM concentrations in the muscle tissues and national and international guidelines for the HMs are summarized in Table 4. The Cd concentrations in the muscle tissue samples from sites S1, S3, S4, S6, and S7 (2.45-5.18 mg/kg ww) exceeded the relevant limits for $\mathrm{Cd}(1-2 \mathrm{mg} / \mathrm{kg} \mathrm{ww})$. The As concentrations in the samples from sites S4 and S7 (0.6 and $3.84 \mathrm{mg} / \mathrm{kg} \mathrm{ww}$, respectively) exceeded the Chinese national guideline of $0.5 \mathrm{mg} / \mathrm{kg} \mathrm{ww}$. The $\mathrm{Cr}, \mathrm{Cu}, \mathrm{Pb}$, and $\mathrm{Zn}$ concentrations $(0.21-0.64,0.98-$ $2.76,0.04-0.71$, and $18.94-60.97 \mathrm{mg} / \mathrm{kg} \mathrm{ww}$, respectively) were within the relevant limits $(2,50,1.0-1.5$, and $100 \mathrm{mg} / \mathrm{kg} \mathrm{ww}$, respectively).

The potential health risks posed by HMs in Rud to humans were estimated by calculating THQs and $\mathrm{CR}_{\max } \mathrm{S}$ according to Equations 2 and 3. The results are summarized in Tables 5 and 6. Inorganic As is more toxic than organic As, and the calculations were performed assuming that inorganic As contributed 3\% of the total As concentrations (Li et al., 2015). 
Table 4. Heavy metal concentrations in the muscle tissues of Rud from Liaodong Bay. (mg/kg w.w.)

\begin{tabular}{c|c|c|c|c|c|c|c|c}
\hline & Safety & \multicolumn{7}{|c}{ Heavy metal concentrations } \\
\cline { 3 - 8 } & guidelines & S1 & S2 & S3 & S4 & S5 & S6 & S7 \\
\hline $\mathrm{Cd}$ & $1^{\mathrm{b}}, 2^{\mathrm{d}}$ & 2.45 & 1.78 & 3.74 & 3 & 1.82 & 5.18 & 4.91 \\
$\mathrm{Cr}$ & $2^{\mathrm{a}, \mathrm{b}}$ & 0.64 & 0.21 & 0.32 & 0.36 & 0.37 & 0.47 & 0.23 \\
$\mathrm{As}$ & $0.5^{\mathrm{a}, \mathrm{b}}$ & 0.49 & 0.39 & 0.35 & 0.61 & 0.38 & 0.4 & 3.84 \\
$\mathrm{Cu}$ & $50^{\mathrm{b}}$ & 0.98 & 2.33 & 2.76 & 2.45 & 2.13 & 2.38 & 2.04 \\
$\mathrm{Zn}$ & $150^{\mathrm{e}}$ & 26.75 & 18.94 & 24.87 & 22.66 & 60.97 & 34.79 & 40.79 \\
$\mathrm{~Pb}$ & $1.0^{\text {bd }}, 1.5^{\mathrm{c}}$ & 0.21 & 0.09 & 0.18 & 0.2 & 0.71 & 0.3 & 0.04 \\
\hline
\end{tabular}

Table 5. Estimated target hazard quotient (THQ) for Rud

\begin{tabular}{c|c|c|c|c|c|c|c|c}
\hline \multirow{2}{*}{ HMs } & $\begin{array}{c}\text { RfD } \\
\text { (mg/kg·day) }\end{array}$ & \multicolumn{9}{|c}{ THQ } \\
\cline { 3 - 8 } & $5 \times 10^{-4}$ & $\mathbf{3 . 0 3}$ & $\mathbf{2 . 2 0}$ & $\mathbf{4 . 6 2}$ & $\mathbf{3 . 7 1}$ & $\mathbf{2 . 2 5}$ & $\mathbf{6 . 4 0}$ & $\mathbf{6 . 0 6}$ \\
$\mathrm{Cd}$ & $3 \times 10^{-3}$ & 0.13 & 0.04 & 0.07 & 0.07 & 0.08 & 0.09 & 0.05 \\
$\mathrm{Cr}$ & $3 \times 10^{-4}$ & 0.03 & 0.02 & 0.02 & 0.04 & 0.02 & 0.03 & 0.24 \\
$\mathrm{As}$ & $4 \times 10^{-2}$ & 0.02 & 0.04 & 0.04 & 0.04 & 0.03 & 0.04 & 0.03 \\
$\mathrm{Cu}$ & $3 \times 10^{-1}$ & 0.06 & 0.04 & 0.05 & 0.05 & 0.13 & 0.07 & 0.08 \\
$\mathrm{Zn}$ & $1 \times 10^{-2}$ & 0.01 & 0.01 & 0.01 & 0.01 & 0.04 & 0.02 & 0.00 \\
$\mathrm{~Pb}$ & &
\end{tabular}

Table 6. Estimated maximum consumption rates $\left(C R_{\max }\right)$ for $R u d$

\begin{tabular}{c|c|c|c|c|c|c|c}
\hline \multirow{2}{*}{ HMs } & \multicolumn{7}{|c}{ CR $_{\max }$ (g w.w.) } \\
\cline { 2 - 8 } & $\mathbf{S 1}$ & $\mathbf{S 2}$ & $\mathbf{S 3}$ & $\mathbf{S 4}$ & $\mathbf{S 5}$ & $\mathbf{S 6}$ & S7 \\
\hline $\mathrm{Cd}$ & 12.86 & 17.70 & 8.42 & 10.50 & 17.31 & 6.08 & 6.42 \\
$\mathrm{Cr}$ & 295.31 & 900.00 & 590.63 & 525.00 & 510.81 & 402.13 & 821.74 \\
$\mathrm{As}$ & 1285.71 & 1615.38 & 1800.00 & 1032.79 & 1657.89 & 1575.00 & 164.06 \\
$\mathrm{Cu}$ & 2571.43 & 1081.55 & 913.04 & 1028.57 & 1183.10 & 1058.82 & 1235.29 \\
$\mathrm{Zn}$ & 706.54 & 997.89 & 759.95 & 834.07 & 309.99 & 543.26 & 463.35 \\
$\mathrm{~Pb}$ & 3000.00 & 7000.00 & 3500.00 & 3150.00 & 887.32 & 2100.00 & 15750.00 \\
\hline
\end{tabular}

A THQ $\leq 1$ was taken to indicate no risks were posed to humans, and a THQ $>1$ was taken to mean risks were posed to humans ( $\mathrm{Li}$ et al., 2015). The Cd THQs (2.1896.397) were higher than the other metal THQs for all the sampling sites. The concentrations of the HMs other than Cd in Rud from all of the sampling sites were found not to pose significant risks to humans (THQ $<1$ ).

HMs can accumulate in Rud. Consuming certain amounts of contaminated Rud could therefore cause adverse health effects. $\mathrm{CR}_{\max } \mathrm{S}$ for theHMs in Rud were therefore calculated. The $\mathrm{Pb} \mathrm{CR} \max$ s were relatively high, at $887.32-15750.00 \mathrm{~g} \mathrm{ww})$. The $\mathrm{Cd}$ $\mathrm{CR}_{\max } \mathrm{s}$ (6.08-17.70 $\mathrm{g} \mathrm{ww}$ ) were lower than the $\mathrm{CR}_{\max } \mathrm{s}$ for the other HMs, meaning the probability of health risks being posed to humans consuming $R u d$ from Liaodong Bay was higher for $\mathrm{Cd}$ than the other HMs. 


\section{Discussion}

\section{HMs in Rud}

Liaodong Bay is the largest bay in the Bohai Sea. A complete water exchange cycle in Liaodong Bay takes 15 y (Wan et al., 2008a). Many rivers (including the Cishanhe River, Dalinghe River, Liaohe River, Shuangtaizihe River, Xiaolinghe River, and Wulihe River) discharge into Liaodong Bay. These rivers are thought to be important sources of HMs to Liaodong Bay (Wan et al., 2008b). The Cd concentrations in the samples from all of the sampling sites were quite high, and the concentration in the muscle samples from site S6 exceeded the Category III standard for Cd. This indicated that attention needs to be paid to $\mathrm{Cd}$ pollution in Liaodong Bay. The $\mathrm{Cr}$ and $\mathrm{Pb}$ concentrations were higher in the samples from sites S1 and S5, respectively, than in the samples from the other sites but lower than the Category II standards. The As concentrations in the viscera samples from site S7 exceeded the Category II standard for As, and the Zn concentrations in the viscera samples from sites S5 and S7 exceeded the Category II standards. These results indicated that the sites mentioned may be contaminated with these $\mathrm{HMs}$. The $\mathrm{Pb}$ concentrations were not high. $\mathrm{Pb}$ and its salts can cause kidney damage and negatively affect the nervous system. Even low $\mathrm{Pb}$ concentrations in food cannot be ignored (Gao et al., 2014).

Compared with other domestic and international bays, Liaodong Bay has higher $\mathrm{Cd}$ concentration in shellfish (Lei et al., 2013; Li et al., 2015; Liu et al., 2017; Gu et al., 2016; Copat et al., 2013; Jovic and Stankovic, 2014; Alfonso et al., 2013). Cd pollution is worthy of attention.

\section{Tissue-specific differences in HM concentrations}

In clams, HMs tend to accumulate more efficiently in viscera than muscles (Husmann et al., 2012; Sarkar et al., 2008; Liu et al., 2017). Viscera play important roles in metabolic processes related to HMs. The hepatopancreas and kidney play important roles in HM absorption, transport, storage, and excretion. HMs in muscle tissue can be removed relatively quickly. In this study, $\mathrm{As}, \mathrm{Cr}$, and $\mathrm{Cu}$ had similar tissue-specific accumulation characteristics. The concentrations of these HMs were higher in the viscera than the muscles. In contrast, the $\mathrm{Cd}$ concentrations were higher in the muscles than the viscera. Similar results have been found in previous studies (Liu et al., 2017; Tarque et al., 2012). Insufficient data were available to explain this. In aquatic environments, $\mathrm{Cd}$ is mainly in the dissolved phase. $\mathrm{Cd}$ may easily be absorbed by tissues it comes into contact with (e.g., the mantle) in Rud. Large amounts of Cd may therefore accumulate in the mantle (Liu et al., 2017). This could explain the $\mathrm{Cd}$ concentrations being higher in the muscle samples than the viscera samples. $\mathrm{Zn}$ is an essential element that is absorbed and eliminated through various physiological processes in different tissues. Excess Zn may accumulate in the mantle of a clam. These factors may affect $\mathrm{Zn}$ accumulation in the muscles and viscera and explain the $\mathrm{Zn}$ concentrations in the muscle and viscera samples not being different.

\section{Geographical differences in HM concentrations}

HM contamination of Rud was more severe in the west of Liaodong Bay (at sites S4S7) than in the east (sites S1-S3). Geographical variations in HM concentrations in clams are generally considered to be related to the distributions and characteristics of 
local sources of pollutants. The sampling sites along the west coast of Liaodong Bay were in Jinzhou Bay, a small cove in the northwestern part of Liaodong Bay. Jinzhou Bay has been contaminated by industrial effluent from chlor-alkali plants, petrochemical plants, the Huludao zinc plant, and the Bohai shipyard (Gao et al., 2014). Water in Liaodong Bay and the open sea is exchanged quite weakly, so HMs are not quickly transported from Liaodong Bay into the open sea. HMs released into Liaodong Bay can therefore accumulate in aquatic environmental media (e.g., sediment and clams).

\section{Assessment of the risks posed by HMs in Rud to humans}

The Cd concentrations in the muscle samples from sites S1, S3, S4, S6, and S7 exceeded the relevant limit. In particular, the $\mathrm{Cd}$ concentrations in the samples from site S6 exceeded the limit by a factor of $\sim 2.5$. The Cd THQs for all of the sampling sites were $>1$ and were higher than the THQs for the other metals. The Cd CR $\mathrm{max}_{\text {S }}$ (6.08$17.70 \mathrm{~g} \mathrm{ww}$ ) were lower than the $\mathrm{CR}_{\max } \mathrm{S}$ for the other HMs that were analyzed. These results indicated that $\mathrm{Cd}$ would pose health risks to humans consuming Rud from the study area.

Industrial and other human activities are the main causes of $\mathrm{Cd}$ entering the environment. $\mathrm{Cd}$ can effectively accumulate in clams. $\mathrm{Cd}$ is very toxic to humans and can seriously affect the structures and functions of the bones, central nervous system (including the brain), kidneys, lungs, liver, and placenta. The Rud in the study area were heavily contaminated with $\mathrm{Cd}$. Humans living around Liaodong Bay and consuming local Rud for a long period may be exposed to risks posed by $\mathrm{Cd}$.

Rud was the only source of HMs to humans considered in the risk assessments performed in this study. Other sources include other types of seafood, rice, vegetables, and water, but these were not included in the risk assessments. The health risks found to be posed by HMs to humans in the risk assessments would have been stronger if all possible sources of HMs were considered.

\section{Conclusions}

The Cd concentrations were quite high in the samples from Liaodong Bay. The $\mathrm{Cd}$ concentrations in the samples from sites S6 and S7 were in the Category III standard for $\mathrm{Cd}$. The concentrations of $\mathrm{Cr}$ in the samples from site $\mathrm{S} 1$, As in the samples from site $\mathrm{S} 7, \mathrm{~Pb}$ in the samples from site $\mathrm{S} 5$, and $\mathrm{Zn}$ in the samples from sites $\mathrm{S} 5$ and $\mathrm{S} 7$ were also quite high. The Rud samples had typical tissue-specific heavy metal bioaccumulation patterns. Cd tended to accumulate more efficiently in muscle than viscera, whereas $\mathrm{As}, \mathrm{Cr}$ and $\mathrm{Cu}$ tended to accumulate more efficiently in viscera than muscles. $\mathrm{Pb}$ and $\mathrm{Zn}$ were not significantly different in the muscle and viscera samples. Heavy metal contamination of Rud tended to be worse in the west than the east of Liaodong Bay. The heavy metal THQs and $\mathrm{CR}_{\max }$ s for the muscle samples and national and international guidelines indicated that $\mathrm{Cd}$ was the main source of health risks to humans through consuming Rud from Liaodong Bay.

In summary, $\mathrm{Cd}$ was found to have an impact on the local environment and human health. Effective measures should be taken to control $\mathrm{Cd}$ pollution. Distribution characteristics and the bioaccumulation of HMs in seawater, surface sediments and other marine organisms will be studied in the future in order to take effective measures to control the pollution of HMs. 
Acknowledgements. This study was supported by grants from the National Natural Science Foundation of China (NSFC, No. 31601914), the Key Research and Development Guidance Project of Liaoning Province of China (2018225028).

\section{REFERENCES}

[1] Alfonso, J. A., Handt, H., Mora, A., Vasquez, Y., Azocar, J., Marcano, E. (2013): Temporal distribution of heavy metal concentrations in oysters Crassostrea rhizophorae from the central Venezuelan coast. - Mar. Pollut. Bull. 73(1): 394-398.

[2] Copat, C., Arena, G., Fiore, M., Ledda, C., Fallico, R., Sciacca, S., Ferrante, M. (2013): Heavy metals concentrations in fish and shellfish from eastern Mediterranean Sea: consumption advisories. - Food Chem. Toxicol. 53: 33-37.

[3] Gao, X., Chen CTA (2012): Heavy metal pollution status in surface sediments of the coastal Bohai Bay. - Water Res 46: 1901-1911.

[4] Gao, X., Zhou, F., Chen, C. T. (2014): Pollution status of the Bohai Sea: an overview of the environmental quality assessment related trace metals. - Environment International 62: $12-30$.

[5] Gargouri, D., Azri, C., Serbaji, M. M., Jedoui, Y., Montacer, M. (2011): Heavy metal concentrations in the surface marine sediments of Sfax Coast, Tunisia. - Environ Monit Assess 175: 519-530.

[6] Gu, Y. G., Huang, H. H., Lin, Q. (2016): Concentrations and human health implications of heavy metals inwild aquatic organisms captured from the core area of Daya Bay'sFishery Resource Reserve, South China Sea. - Environmental Toxicology and Pharmacology 45: 90-94.

[7] Hu, B. Q., Li, G. G., Li, J., Bi, J. Q., Zhao, J. T., Bu, R. Y. (2013): Spatial distribution and ecotoxicological risk assessment of heavy metals in surface sediments of the southern Bohai Bay, China. - Environ. Sci. Pollut. Res. 20(6): 4099-4110.

[8] Husmann, G., Abele, D., Monien, P., Kriews, M., Philipp, E. E. R. (2012): The influence of sedimentation on metal accumulation and cellular oxidative stress markers in the Antarctic bivalve Laternula elliptica. - Estrar. Coast. Sgelf Sci. 111: 46-59.

[9] Jovic, M., Stankovic, S. (2014): Human exposure to trace metals and possible public health risks via consumption of mussels Mytilus galloprovincialis from the Adriatic coastal area. - Food Chem. Toxicol. 70: 241-251.

[10] Lei, B. L., Chen, L., Hao, Y., Cao, T. H., Zhang, X. Y., Yu, Y. G., Fu, J. M. (2013): Trace elements in animal-based food from Shanghai markets and associated human daily intake and uptake estimation considering bioaccessibility. - Ecotoxicol. Environ. Saf. 96: 160-167.

[11] Li, P. M., Gao, X. L. (2014): Trace elements in major marketed marine bivalves from six northern coastal cities of China: concentrations and risk assessment for human health. Ecotoxicol. Environ. Saf. 109: 1-9.

[12] Li, Y. H., Liu, H., Zhou, H. L., Ma, W. D., Han, Q., Diao, X. P., Xue, Q. Z. (2015): Concentration distribution and potential health risk of heavy metals in Mactra veneriformis from Bohai Bay, China. - Marine Pollution Bulletin 97: 528-534.

[13] Liang, L. N., He, B., Jiang, G. B., Chen, D. Y., Yao, Z. W. (2004): Evaluation of mollusks as biomonitors to investigate heavy metal contaminations along the Chinese Bohai Sea. - Sci Total Environ.324: 105-113.

[14] Liu, J. H., Gao, L., Dou, S. Z. (2017): Bioaccumulation of heavy metals and health risk assessment in three benthic bivalves along the coast of Laizhou Bay, China. - Marine Pollution Bulletin 117: 98-110.

[15] Liu, W. X., Chen, J. L., Lin, X. M., Fan, Y. S., Tao, S. (2007): Residual concentrations of micropollutants in benthic mussels in the coastal areas of Bohai Sea, North China. Environ Pollut. 146: 470-477. 
[16] MEP (2013): Exposure Factors Handbook of Chinese Population (Adults). - Chinese Environment Press, Beijing (in Chinese).

[17] Naser, H. A. (2013): Assessment and management of heavy metal pollution in the marine environment of the Arabian Gulf: a review. - Mar Pollut Bull 72: 6-13.

[18] National Bureau of Statistics of China (2009): China Yearbook - 2009. http://www.stats.gov.cn/tjsj/ndsj/2009/indexch.htm.

[19] National Physique Monitoring Center of China (2012): Communique of national physical fitness monitoring. - http://www.fitness.org.cn/w/791.html.

[20] Sarkar, S. K., Cabral, H., Chatterjee, M., Cardoso, I., Bhattacharya, A. K., Satpathy, K. K., Alam, M. A. (2008): Biomonitoring of heavy metals using the bivalve molluscs in Sunderban mangrove wetland, northeast coast of Bay of Bengal (India): possible risks to human health. - Clean-Soil Air Water 36: 187-194.

[21] SEPA (State Environmental Protection Administration of China). (2001): Marine Biological Quality (GB 18421-2001). - Standards Press of China, Beijing.

[22] Shoults-Wilson, W. A., Elsayed, N., Leckrone, K., Unrine, J. (2015): Zebra mussels (Dreissena polymorpha) as a biomonitor of trace elements along the southern shoreline of Lake Michigan. - Environ. Toxicol. Chem. 34: 412-419.

[23] Tarque, Q., Burger, J., Reinfelder, J. R. (2012): Metal concentrations in organs of the clam Amiantis umbonella and their use in monitoring metal contamination of coastal sediments. - Water Air Soil Pollut. 223: 2125-2136.

[24] US EPA (2000): Risk-Based Concentration Table. Philadelphia PA. - United States Environmental Protection Agency, Washington, DC.

[25] US EPA (United States Environmental Protection Agency) (2014): Risk-based concentration table. - http://www.epa.gov/reg3hwmd/risk/human/index.htm.

[26] US EPA (2015): Integrated Risk Information System. - http://www.epa.gov/iris.

[27] Wan, L., Wang, N. B., Li, Q. B., Zhou, Z. C., Sun, B., Xue, K., Ma, Z. Q., Tian, J., Du, N. (2008a): Estival distribution of dissolved metal concentrations in Liaodong Bay. Bull Environ Contam Toxicol. 80: 311-314.

[28] Wan, L., Wang, N. B., Li, Q. B., Sun, B., Zhou, Z. C., Xue, K., Ma, Z., Tian, J., Song, L. (2008b): Distribution of dissolved metals in seawater of Jinzhou Bay, China. - Environ Toxicol Chem. 27: 43-48.

[29] Wang, Y. W., Liang, L., Shi, J. B., Jiang, G. B. (2005): Study on the contamination of heavy metals and their correlations in mollusks collected from coastal sites along the Chinese Bohai Sea. - Environment International 31: 1103-1113.

[30] Wei, Y. H., Zhang, J. Y., Zhang, D. W., Tu, T. H., Luo, L. G. (2014): Metal concentrations in various fish organs of different fish species from Poyang Lake, China. Ecotoxicol. Environ. Saf. 104: 182-188.

[31] Won, E. J., Kim, K. T., Choi, J. Y., Kim, E. S., Ra, K. (2016): Target organs of the Manila clam Ruditapes philippinarum for studying metal accumulation and biomarkers in pollution monitoring: laboratory and in-situ transplantation experiments. - Environ. Monit. Assess. 188: 10.

[32] Zhang, Y., Lu. X. Q., Wang. N. L., Xin. M. N., Geng. S. W., Jia. J., Meng. Q. H. (2016): Heavy metals in aquatic organisms of different trophic levels and their potential human health risk in Bohai Bay, China. - Environ Sci Pollut Res. 23: 17801-17810.

[33] Zhao, L. Q., Yang, F., Yan, X. W., Huo, Z. M., Zhang, G. F. (2012): Heavymetal concentrations in surface sediments and Manila clams (Ruditapes philippinarum) from the Dalian coast, China after the Dalian port oil spill. - Biol. Trace Elem. Res. 149: 241247. 